\title{
Shield Modelling of Boron Neutron Capture Therapy Facility with Kartini Reactor's Thermal Column as Neutron Source using Monte Carlo N Particle Extended Simulator
}

\author{
Martinus I Made Adrian Dwiputra ${ }^{1}$, Andang Widi Harto ${ }^{1}$, Yohannes Sardjono², \\ Gede Sutisna Wijaya ${ }^{2}$
}

\author{
${ }^{1}$ Department of Physics Engineering Faculty of Engineering Universitas Gadjah Mada, Jalan \\ Grafika 2, Yogyakarta 55281, Indonesia \\ ${ }^{2}$ Pusat Sains dan Teknologi Akselerator (PSTA) BATAN, Jl. Babarsari Kotak Pos 6101 ykbb, \\ Yogyakarta 55281,Indonesia
}

Received: 12 September 2015, Revised: 30 February 2016, Accepted: 26 August 2016

\begin{abstract}
Studies were carried out to design a shielding for BNCT facility in the end of Kartini reactor's thermal column with predesigned collimator. The design consist of selecting the material and their thickness. The shielding is required to absorb the leaking radiation until the Dose Limit Value of $20 \mathrm{mSv} / \mathrm{year}$ for radiation worker is met. The material considered were paraffin, barite concrete, borated polyethylene, stainless steel 304 and lead. The calculation was done using MCNPX tally facility with converted dose limit value of $10.42 \mu \mathrm{Sv} /$ hour. Design number two were chosen as the best from three designs which surrounded a room with length, width and height of, respectively $200 \mathrm{~cm}, 200 \mathrm{~cm}$ and $166.4 \mathrm{~cm}$. The first and main layer are borated polyethyelene and barite concrete of 20 and $30 \mathrm{~cm}$, respectively. The additional layer are borated polyethyelene and barite concrete of $15 \mathrm{~cm}$ and $15 \mathrm{~cm}$ with less volume than the main layer to decrease the primary straight radiation from the thermal column. Maximum radiation dose rate is $7.0746 \mu \mathrm{Sv} /$ hour in cell 227 with average dose rate of $2.58712 \mu \mathrm{Sv} /$ hour.
\end{abstract}

Keywords radiation shielding, design, BNCT, MCNPX, thermal column

\section{INTRODUCTION}

The biological effect of radiation on human divided into two categories: the deterministic effect and the stocasthic effect. The deterministic effect occurs due to exposure of high dose radiation. This effect has a certain treshold and has an increasing level of impact with increasing dose. The stocasthic effect occurs probabilistically on individual who is exposed by radiation directly or indirectly. The example of stocasthic effects are cancer and gene mutation. The probability increases as the increasing of exposure and dose. All the effects caused by radiation require a regulation to determine whether an activity using radiation is allowed or not comparing the risk and the profit. (Cember \& Johson, 2009)

This research of BNCT in Kartini Reactor is utilizing a thermal column neutron source.
Inside the thermal column was installed a colimator as in (Warfi, 2015) to shapes and direct the radiation beam into the irradiation room. This room requires shielding around it to absorb the radiation and minimize the leaking radiation, whether it is neutron or photon, so that the radiation dose limit is met. The shielding design is based on the regulation conduct by Nuclear Energy Regulatory Agency (BAPETEN).

The shielding design research of BNCT facility treatment room with D-T neutron source using MCNP-4C code was performed by Mehdi Pouryavi. The research determined the relation of shielding's geometry and thickness which included primary wall, secondary wall, monitoring window and entrance door from the treatment room with the dose outside the room. The shielding materials for neutron and 
Martinus I Made Adrian Dwiputra, Andang Widi Harto, Yohannes Sardjono, Gede Sutisna Wijaya, Shield Modelling of Boron Neutron Capture Therapy Facility with Kartini Reactor's Thermal Column as Neutron Source Using Monte Carlo N Particle Extended Simulator

photon radiation are lead, ordinary concrete, borated polyethylene dan plain glass for the monitoring window. The results showed that the dose outside the treatment room was under the dose value limit according to NCRP 151 reccomendation. This research was chosed as a reference to choose the shielding material and to designt the geometry of the treatment room. (Pouryavi, 2015)

A research about the properties of some alloy materials for neutron and photon shielding was investigated as in (Singh \& Badiger, 2014) . The alloy materials are CS-516, SS-403, SS410, SS-316, SS-316L, SS-304L, Incoloy-600, Monel-400 and Cupero-Nickel. The conlusion was the best material for photon shielding is Cupero-Nickel and for neutron shielding is SS304L. This research was taken as a reference to deternine the material to design the neutron and photon shielding.

Mohd Rafi Mohd Sollehhas conducted a research to design neutron and photon radiation shielding for the BNCT facility TRIGA MARK II reactor in Malaysia. The materials are polyethylene for neutron shielding and lead for photon shielding. This research was taken as a reference to consider the material for designing the radiation shielding. (Solleh, et al., 2011)

A neutron shielding material is preferred to be reusable due to the impact to the environment for the long term aspect when the facility no longer active. The material should be chosed as in (Calzada, 2011) which is a reusable material as used in ANTARES nuclear facility. The research was conducted using MCNP5 which also concerned in designing a shield that possessed less oxygen, aluminium, silicon, calcium and magnesium that proved to be ineffective to absorb neutron and photon.

Dose calculation have to be precise in order to be able to design a proper radiation shielding. A new analytical formula for neutron capture gamma dose calculations in double-bend mazes in radiation therapy has been studied as in (Ghiasi, 2012). The results is for capture gamma dose equivalents at the maze entrance door, the difference of $2-11 \%$ was seen between MC and the derived equation, while the difference of $36-87 \%$ was found between MC and the $\mathrm{Wu}-\mathrm{McGinley}$ methods.

The neutron and gamma-ray shielding properties of concrete containing different proportions of barite as an aggregate have been investigated as in (Akkurt \& El-Khayatt, 2013). The macroscopic fast neutron removal crosssections have been calculated and compared with the attenuation of gamma-rays with $8 \mathrm{MeV}$ photon energy, because for most shields the neutron produced at $8 \mathrm{MeV}$ are most likely to penetrate. The calculation of neutron removal cross-section has been done by using NXcom program and the photon linear attenuation coefficients were obtained via XCOM code. The best values of barite proportion and density of concrete for maximum shielding against both neutrons and gamma-rays have been determined graphically. The transmission of both gamma rays and neutrons has been obtained as a function of thickness of concrete for all concrete types. It was found that increasing barite proportion in the concrete increased the gamma attenuation coefficient while it decreased the neutron removal cross-section.

\section{MATERIALS AND METHODS}

This research was performed by simulating the irradiation facility for BNCT therapy. The tools and equipments are a laptop with specification as follows: $2.30 \mathrm{GHz}$ processor, Core i5, 4GB RAM and Windows 764 bit operating system, a MCNP-X code to simulate the radiation interaction with matters, Microsoft Office Excel to organize the data and to make graphs. 
The dose value limit that used is according to the Decree of Head of Nuclear Energy Regulatory Agency number 4 year 2013 chapter 15 that states the dose value limit for radiation worker must not exceed $20 \mathrm{mSv}$ per year in 5 years period, so the accumulation dose in 5 years must not exceed $100 \mathrm{mSv}$ (BAPETEN, 2013). The value of $20 \mathrm{mSv} / \mathrm{year}$ then must be converted for a more applicable calculation with dose rate per hour. The conversion was done using the assumption of working time of the radiation worker as in Equation (1).

$\frac{\text { hour }}{\text { day }} \times 5 \frac{\text { day }}{\text { week }} \times 4 \frac{\text { week }}{\text { month }} \times 12 \frac{\text { month }}{\text { year }}=1920 \frac{\text { hour }}{\text { year }}$

The allowed dose value limit was then calculated using Equation (2):

$20000 \frac{\mu \mathrm{Sv}}{\text { year }}: 1920 \frac{\text { hour }}{\text { year }}=10,41667 \frac{\mu \mathrm{Sv}}{\text { hour }} \approx 10.42 \frac{\mu \mathrm{Sv}}{\text { hour }}$

The MCNPX code was used in this research to determine the neutron and photon parameter that affiliates with the radiation level. This parameter was acquired with tally facility. Tally was used to record the neutron and photon radiation energy that emerged from the reactor's core through thermal column. Imp:n or imp:p must be determine in the part of the reactor which considered to be relevant with the dose calculation because only neutron and photon reactions are being considered. (Pelowitz, 2008)

Kartini reactor operates with optimum power of $100 \mathrm{~kW}$. This was used as a normalization factor in the calculation by converting the power into fission rate. The result showed that to produce a power of $100 \mathrm{~kW}$ requires $3.121 \times 10^{15}$ fission/ second. This result then used as a normalization factor for the tally calculation with an average number of neutron per fission of 2.42 and number of photon per second is $7.553 \times 10^{15}$ $\mathrm{n} / \mathrm{s}$. Normalization factor for photon calculation with power conversion 1 photon per fission was achieved. The number of photon per fission is $3.121 \times 10^{15} \square / \mathrm{s}$. (Lamarsh, 1983)

The dose rate calculation requires kerma conversion to convert the energy emitted by neutron and photon into a dose function. The data base was from the kerma coefficient in Dosimetry System 2002 (DS02). (koefisien kerma) This conversion applied into MCNPX program through the command of DEn and DFn. DEn represents the energy in which will be converted, and DFn represents the value of the converted dose from the energy. The next phase of dose rate calculation is to divide the radiation according to its energy and then to determine its quality factor as shown in table 1. This division is required to achieve dose rate in Sievert unit, adapting with the BAPETEN regulation which used Sievert unit. (Stella, 2011)The dose rate calculation involved soft tissue as a material to absorb the dose leaking from the shielding. It consist of substances as found from International Commission Radiation Protection Publication (ICRP) 23 which then converted into MCNPX code. The substances are shown in Table II. (Protection, 1975)

The irraditation room has a simple design as required by National Nuclear Energy Agency (BATAN) for in vivo and in vitro trials. The main layer was designed as a homogenous layer to facilitate the tally volume calculation. The additional layer consist of two layers, named the second layer and third layer, was designed as a beam cather. The beam catcher was required to absorb the radiation from the primary beam which has the biggest intensity and energy because the position is straight from the thermal column. The beam catcher thickness and volume designed to be smaller than the main layer.

The dose rate calculation involved soft tissue as a material to absorb the dose leaking from the shielding. It consist of substances as 
Martinus I Made Adrian Dwiputra, Andang Widi Harto, Yohannes Sardjono, Gede Sutisna Wijaya, Shield Modelling of Boron Neutron Capture Therapy Facility with Kartini Reactor's Thermal Column as Neutron Source Using Monte Carlo N Particle Extended Simulator

Tabel 1. Quality factor of photon and neutron radiation

\begin{tabular}{cc}
\hline Radiation & Quality Factor \\
\hline Photon & 1 \\
Neutron & \\
$(\mathrm{E}<500 \mathrm{keV})$ & 5 \\
$(0,5 \mathrm{MeV}<\mathrm{E}<1 \mathrm{MeV})$ & 10 \\
$(1 \mathrm{MeV}<\mathrm{E}<2,5 \mathrm{MeV})$ & 13 \\
$(2,5 \mathrm{MeV}<\mathrm{E}<20 \mathrm{MeV})$ & 20 \\
\hline
\end{tabular}

found from International Commission Radiation Protection Publication (ICRP) 23 which then converted into MCNPX code. The substances are shown in Table II. (Protection, 1975)

The irraditation room has a simple design as required by National Nuclear Energy Agency (BATAN). The main layer was design as a homogenous layer to facilitate the tally volume calculation. The additional layer consist of two layers, named the second layer and third layer, was designed as a beam cather. The beam catcher was required to absorb the radiation from the primary beam which has the biggest intensity and energy because the position is straight from the thermal column. The beam catcher thickness and volume designed to be smaller than the main layer.

The predesigned collimator was of (Warfi, 2015) with the geometry as shown in Figure 1. The specifications are as follow. The wall is made from $5 \mathrm{~cm}$ thick Nickel, $30 \mathrm{~cm}$ Sulfur as moderator, $2 \mathrm{~cm}$ Bismuth as photon reducer. Diameter of the aperture is $8 \mathrm{~cm}$.
Table 2. Substances in soft tissue used in shielding design to record the leaking radiation dose

\begin{tabular}{ccc}
\hline Substance & $\begin{array}{c}\text { MCNP } \\
\text { Material Code }\end{array}$ & $\begin{array}{c}\text { Weight } \\
\text { fraction, Wt }\end{array}$ \\
\hline $\mathrm{H}$ & 1001 & 0,10454 \\
$\mathrm{C}$ & 6012 & 0,22663 \\
$\mathrm{~N}$ & 7014 & 0,02490 \\
$\mathrm{O}$ & 8016 & 0,63525 \\
$\mathrm{Na}$ & 11023 & 0,00112 \\
$\mathrm{Mg}$ & 12000 & 0,00013 \\
$\mathrm{Si}$ & 14000 & 0,00030 \\
$\mathrm{P}$ & 15031 & 0,00314 \\
$\mathrm{~S}$ & 16032 & 0,00204 \\
$\mathrm{Cl}$ & 17000 & 0,00133 \\
$\mathrm{~K}$ & 19000 & 0,00208 \\
$\mathrm{Ca}$ & 20000 & 0,00024 \\
$\mathrm{Fe}$ & 26000 & 0,00005 \\
$\mathrm{Zn}$ & 30000 & 0,00003 \\
$\mathrm{Rb}$ & 37087 & 0,00001 \\
$\mathrm{Zr}$ & 40000 & 0,00001 \\
\hline
\end{tabular}

The designed irradiation room has the length, width and height of, respectively 200 $\mathrm{cm}, 200 \mathrm{~cm}$ and 166,4 $\mathrm{cm}$ as required by BATAN for in vitro and in vivo tests. The room is a blank room containing only air. The soft tissue embedded surroundings the room because the radiation is isotropic, spreads in all direction. The visualization are shown in Figure 2.

This research chose five materials as a shielding with various thickness. These materials were first tested to determine which has the best performance. The chosen materials are lead $(\mathrm{Pb})$, paraffin, stainless steel 304 , barite concrete and borated polyethylene. All five of

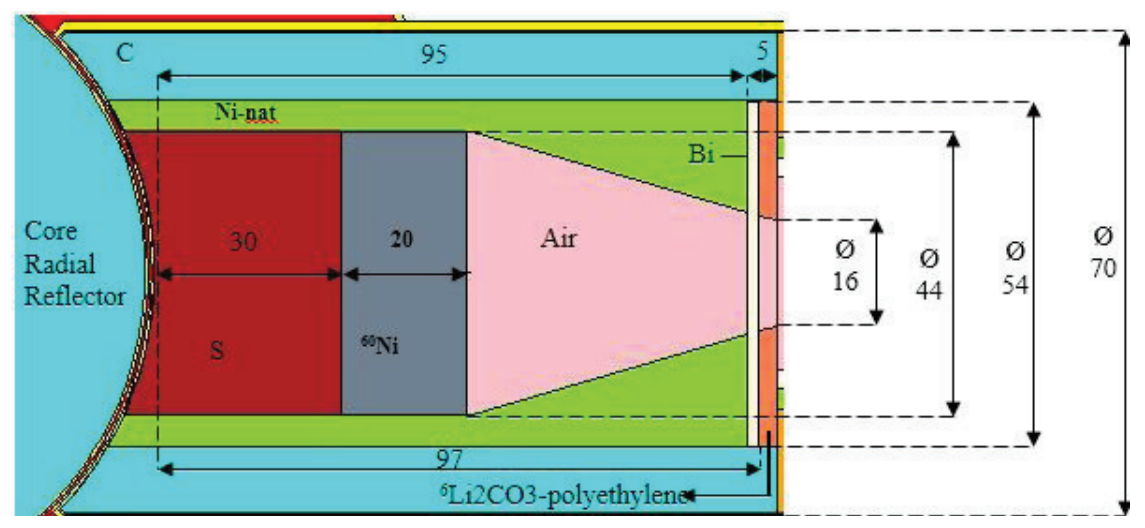

Figure 1. The Predesigned Collimator 


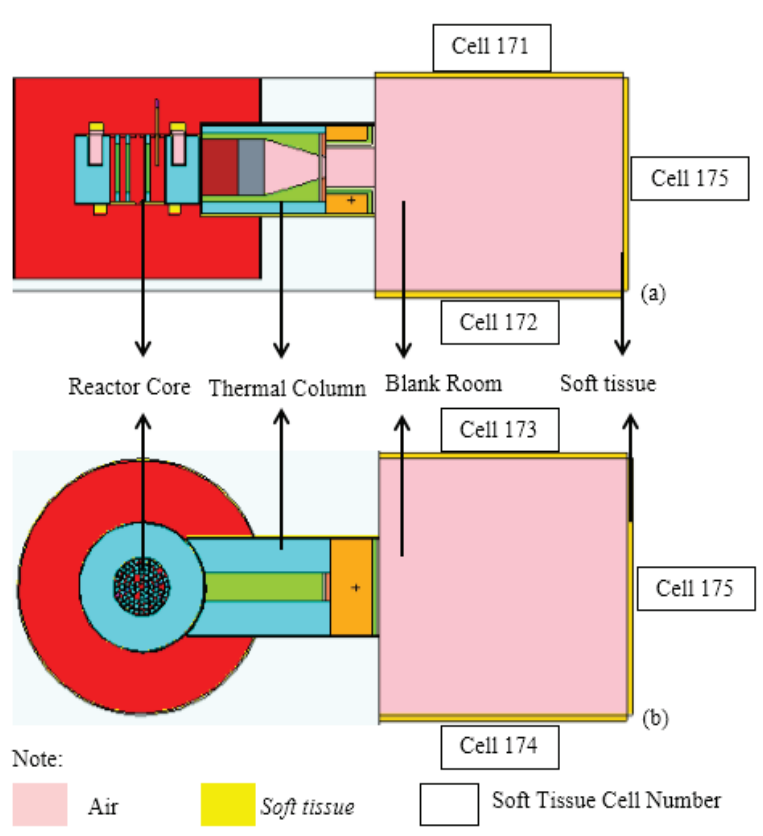

Figure 2.The Room Modelling to Calculate the Dose Outside The Room Without Any Shielding: (a) Side View (b) Top View.

these materials then simulated using MCNPX to shield the radiation which emitted from the collimator in thermal column with thickness variation of $10 \mathrm{~cm}$, starting from $10 \mathrm{~cm}$ until $100 \mathrm{~cm}$ as shown in Figure 3. (Santoso, 2014) (Pouryavi, 2015)

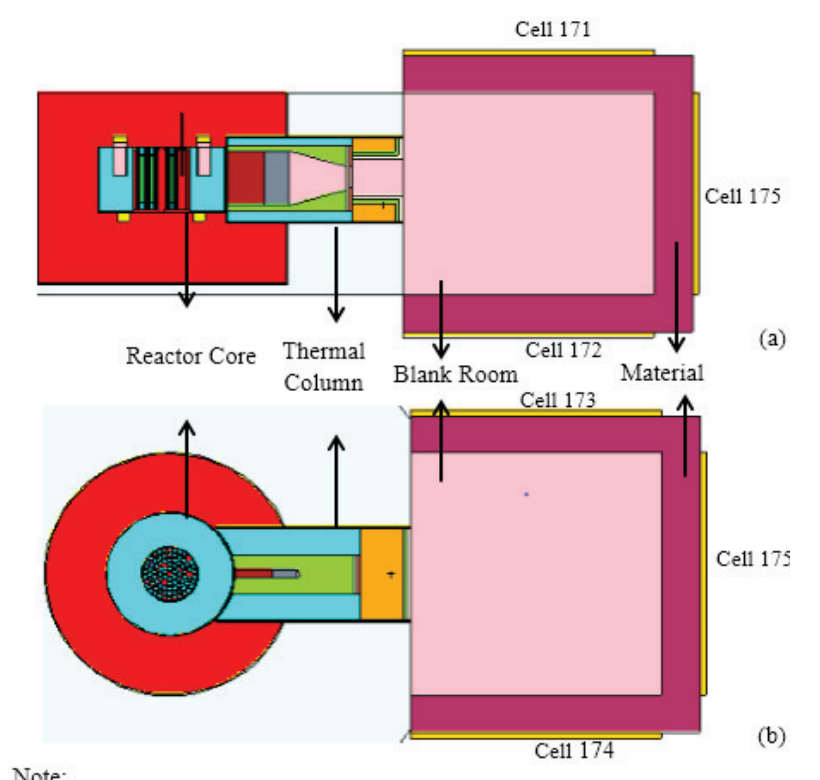

Note:

$$
\text { Soff tissue Air }
$$

Figure 3.Material Testing With Various Thickness: (a) Side View (b) Top View.

\section{RESULTS AND DISCUSSION}

The material simulation resulted and plotted in a graph to provide a better assesment of the materials. Five tally cells recorded the leaking radiation through the shielding material as shown in Figure 4.

In figure 4 are shown that paraffin and borated polyethylene has the best capacitancy to absorb the radiation under $40 \mathrm{~cm}$ thickness because they are hydrocarbon compounds with high neutron cross section but cannot interact well with photon. Over $40 \mathrm{~cm}$ thickness, SS 304 and barite concrete has a better performance compared to paraffin and borated polyethylne because they were able to absorb neutron as well as photon. Lead $(\mathrm{Pb})$ were considered to be the worst from the other materials because it only absorbeb photon. Lead were then erased from the material candidates to design the shielding. After the materials were chosen, the design then were to be made by combining them with various thickness according to their performance in Figure 4.

Design number 1 used paraffin with 20 $\mathrm{cm}$ thickness and barite concrete with $30 \mathrm{~cm}$ thickness as the main layer. The additional layer/beam catcher is $15 \mathrm{~cm}$ paraffin and 15 $\mathrm{cm}$ barite concrete with smaller volume than the main layer to decrease primary dose rate which remain relatively high after the main layer. Visual view of design number 1 are shown in figure 5. The dose rate results from MCNPX code running are shown in table 3 . Design number 2 used borated polyethylene with 20 $\mathrm{cm}$ thickness and barite concrete with $30 \mathrm{~cm}$ thickness as the main layer. The additional layer/ beam catcher is $15 \mathrm{~cm}$ borated polyethylene and $15 \mathrm{~cm}$ barite concrete with smaller volume than the main layer to decrease primary dose rate which remain relatively high after the main layer. Visual view of design number 2 are shown in figure 6 . The dose rate results from MCNPX code running are shown in table 4. 
Martinus I Made Adrian Dwiputra, Andang Widi Harto, Yohannes Sardjono, Gede Sutisna Wijaya, Shield Modelling of Boron Neutron Capture Therapy Facility with Kartini Reactor's Thermal Column as Neutron Source Using Monte Carlo N Particle Extended Simulator

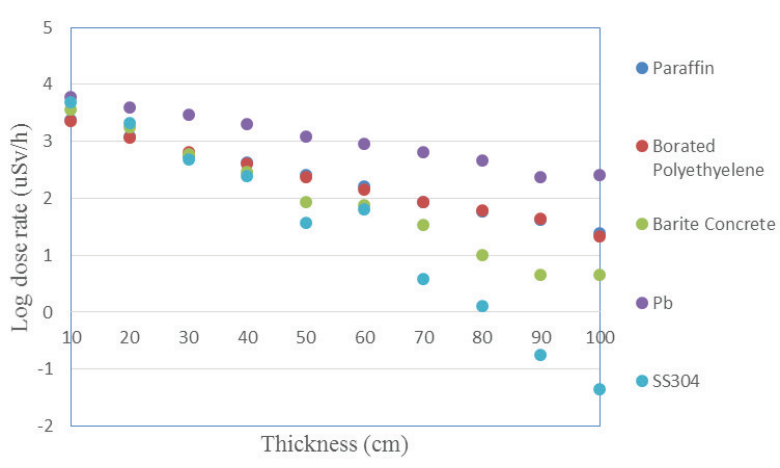

(a)

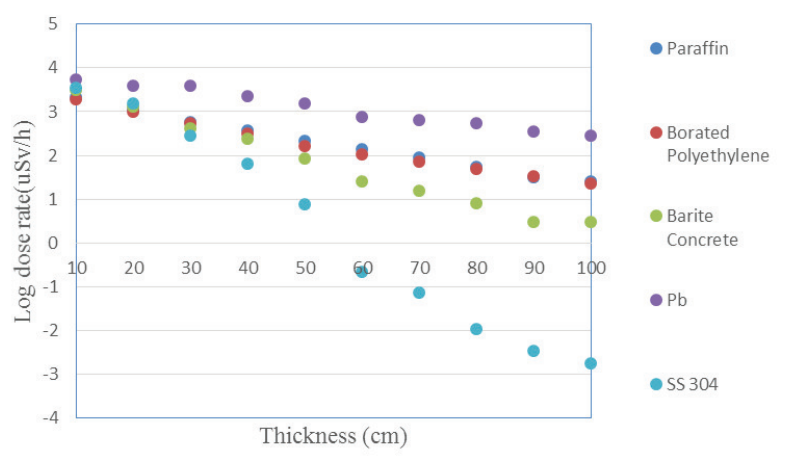

(c)

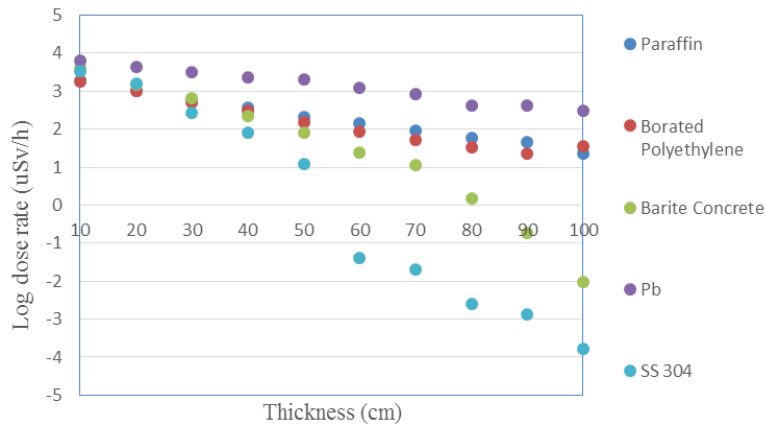

(b)

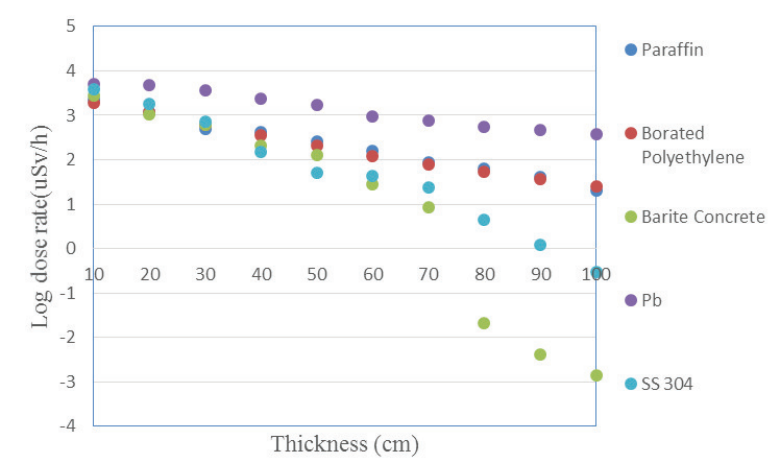

(d)

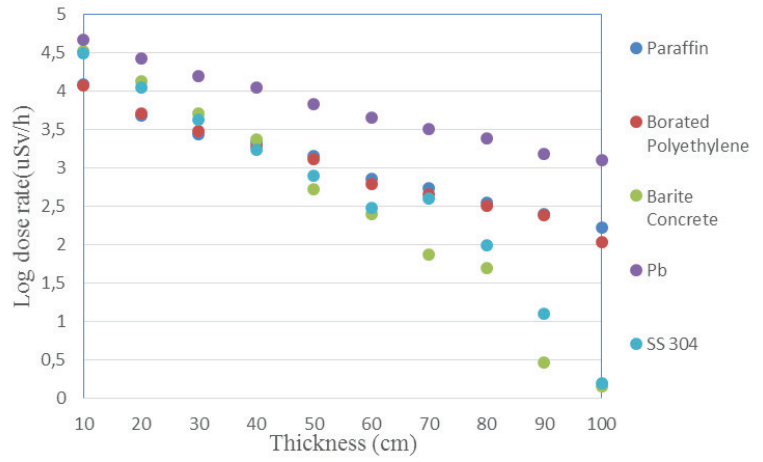

(e)

Figure 4. The radiation dose rate in various material thickness:

(a) cell 171 (b) cell 171 (c) cell 173 (d) cell 174 (e) cell 175

Design number 3 used stainless steel 304 with $30 \mathrm{~cm}$ thickness and barite concrete with 40 $\mathrm{cm}$ thickness as the main layer. The additional layer/beam catcher is $15 \mathrm{~cm}$ barite concrete and $10 \mathrm{~cm}$ barite concrete with smaller volume than the main layer to decrease primary dose rate which remain relatively high after the main layer. Visual view of design number 3 are shown in figure 7. The dose rate results from MCNPX code running are shown in table 5.
All three of the shielding modelling were met with the BAPETEN criteria with dose rate in each of the soft tissue outside the shielding did not exceed $10.42 \mu \mathrm{Sv} / \mathrm{h}$. The best design was chosen based on the minimum dose rate, position of the maximum dose rate, average dose rate and cost estimation of the shielding material. The selection of the best shielding was performed by assessing the summary of three of the designs as shown in table 6 . 


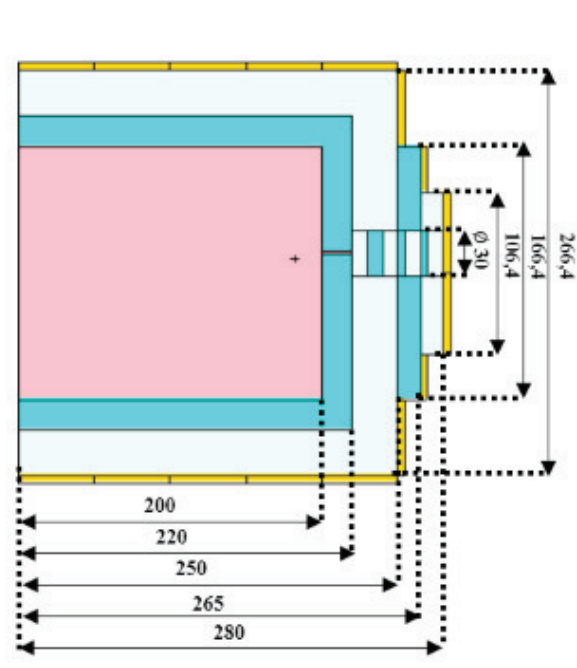

(a)

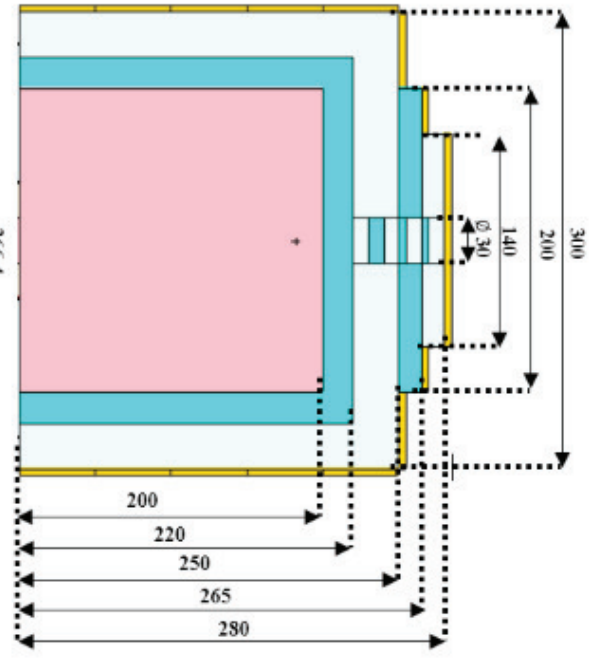

(b)

Note:

Air Paraffin Soft tissue

Figure 5. Radiation shielding design using paraffin and barite concrete: (a) Side view (b) Top view (in cm)

Table 3. Radiation dose rate design 1

\begin{tabular}{cccccc}
\hline Cell & $\begin{array}{c}\text { Radiation Dose } \\
\text { Rate }(\mu \mathbf{S v} / \mathbf{h})\end{array}$ & Cell & $\begin{array}{c}\text { Radiation Dose Rate } \\
(\mu \mathbf{S v} / \mathbf{h})\end{array}$ & Cell & $\begin{array}{c}\text { Radiation Dose Rate } \\
(\mu \mathbf{S v} / \mathbf{h})\end{array}$ \\
\hline 201 & 0.401123 & 211 & 0.626233 & 221 & 3.36768 \\
202 & 1.83624 & 212 & 1.720008 & 222 & 2.995543 \\
203 & 0.770268 & 213 & 4.223532 & 223 & 5.036216 \\
204 & 3.210248 & 214 & 2.389989 & 224 & 3.038388 \\
205 & 1.169198 & 215 & 4.442327 & 225 & 6.574284 \\
206 & 0.68066 & 216 & 0.337133 & 226 & 2.86422 \\
207 & 1.001357 & 217 & 0.222896 & 227 & 7.850856 \\
208 & 1.47564 & 218 & 1.821192 & 228 & 4.60998 \\
209 & 1.983492 & 219 & 2.898408 & 229 & 5.547496 \\
210 & 0.843746 & 220 & 1.472172 & 230 & 2.668152 \\
\hline
\end{tabular}

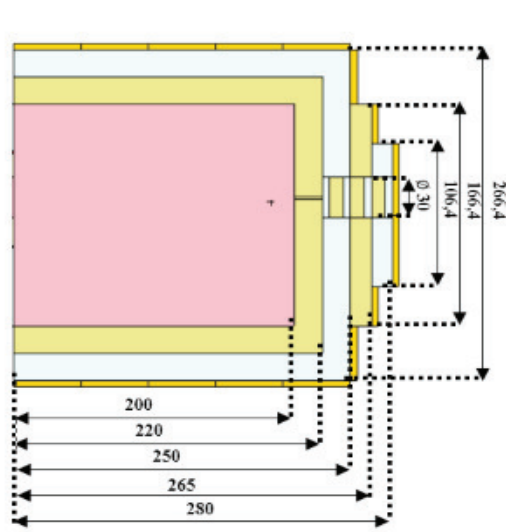

(a)

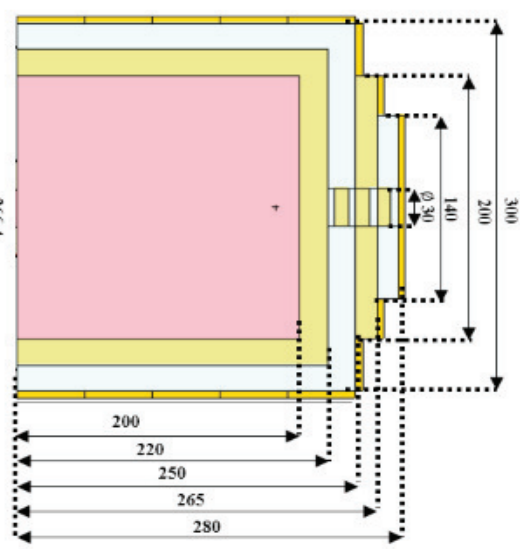

(b)

Note:

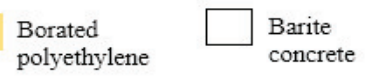
Soft tissue

Figure 6. Radiation shielding using borated polyethylene and barite concrete: (a) Side view (b) Top view (in $\mathrm{cm}$ ) 
Martinus I Made Adrian Dwiputra, Andang Widi Harto, Yohannes Sardjono, Gede Sutisna Wijaya, Shield Modelling of Boron Neutron Capture Therapy Facility with Kartini Reactor's Thermal Column as Neutron Source Using Monte Carlo N Particle Extended Simulator

Table 4.Radiation dose rate design 2

\begin{tabular}{cccccc}
\hline Cell & $\begin{array}{c}\text { Radiation Dose Rate } \\
(\mu \mathbf{S v} / \mathbf{h})\end{array}$ & Cell & $\begin{array}{c}\text { Radiation Dose } \\
\text { Rate }(\boldsymbol{\mu S v} / \mathbf{h})\end{array}$ & Cell & $\begin{array}{c}\text { Radiation Dose Rate } \\
(\boldsymbol{\mu} \mathbf{S v} / \mathbf{h})\end{array}$ \\
\hline 201 & 0.616502 & 211 & 0.856471 & 221 & 2.811428 \\
202 & 0.861882 & 212 & 1.73681 & 222 & 0.498033 \\
203 & 1.812265 & 213 & 3.929048 & 223 & 4.017517 \\
204 & 1.731454 & 214 & 1.91212 & 224 & 4.76938 \\
205 & 0.813348 & 215 & 1.249432 & 225 & 5.348158 \\
206 & 0.16894 & 216 & 0.820838 & 226 & 6.143778 \\
207 & 1.643002 & 217 & 0.835786 & 227 & 7.074603 \\
208 & 2.678638 & 218 & 3.625878 & 228 & 5.250928 \\
209 & 5.875956 & 219 & 2.618788 & 229 & 1.44829 \\
210 & 2.230603 & 220 & 0.570644 & 230 & 3.663223 \\
\hline
\end{tabular}

Table 5. Radiation dose rate design 3.

\begin{tabular}{cccccc}
\hline Cell & $\begin{array}{c}\text { Radiation Dose } \\
\text { Rate }(\mu \mathbf{S v} / \mathbf{h})\end{array}$ & Cell & $\begin{array}{c}\text { Radiation Dose } \\
\text { Rate }(\mu \mathbf{S v} / \mathbf{h})\end{array}$ & Cell & $\begin{array}{c}\text { Radiation Dose Rate } \\
(\mu \mathbf{S v} / \mathbf{h})\end{array}$ \\
\hline 201 & 3.955169 & 211 & 5.571869 & 221 & 3.751515 \\
202 & 2.628454 & 212 & 0.843253 & 222 & 0.263661 \\
203 & 8.124579 & 213 & 4.494559 & 223 & 8.069585 \\
204 & 1.232603 & 214 & 3.554785 & 224 & 1.309021 \\
205 & 0.117475 & 215 & 0.142984 & 225 & 7.681616 \\
206 & 3.616537 & 216 & 4.925832 & 226 & 1.9445 \\
207 & 2.128436 & 217 & 2.405926 & 227 & 5.271798 \\
208 & 6.85009 & 218 & 2.852227 & 228 & 0.03987 \\
209 & 6.66175 & 219 & 3.78374 & 229 & 1.152967 \\
210 & 1.307319 & 220 & 5.629305 & 230 & 0.411839 \\
\hline
\end{tabular}

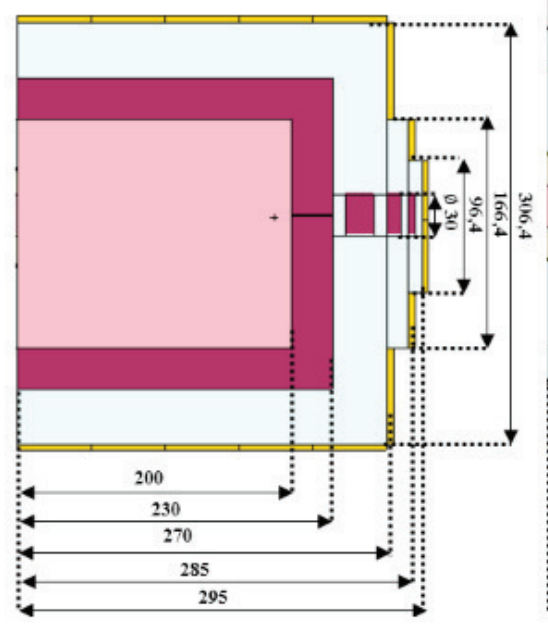

(a)

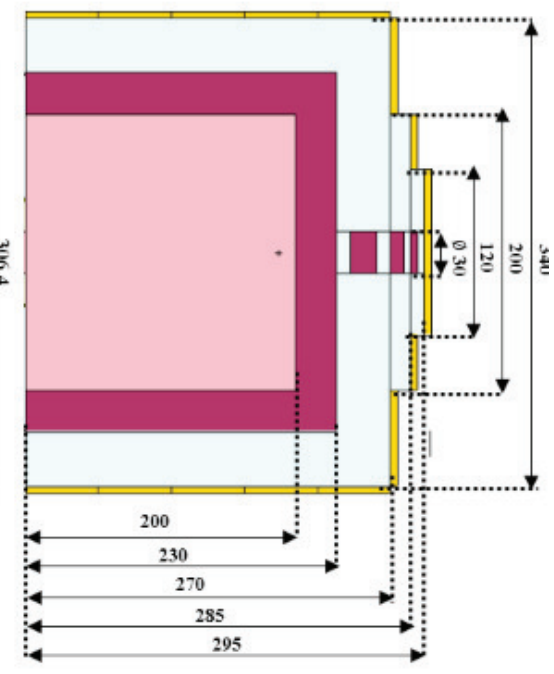

(b)

Note:

Air

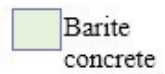

SS 304

Soft tissue

Figure 7. Radiation shielding using stainless steel 304 and barite concrete: (a) Side view (b) Top view (in cm) 
Table 6. Summary of the three designs.

\begin{tabular}{cccc}
\hline & Design 1 & Design 2 & Design 3 \\
\hline Maximum dose rate $(\mu \mathrm{Sv} / \mathrm{h})$ & 7.85086 & 7.0746 & 8.12458 \\
Position of maximum dose rate $($ cell number $)$ & 227 & 227 & 203 \\
Dose rate average $(\mu \mathrm{Sv} / \mathrm{h})$ & 2.60262 & 2.58712 & 3.35744 \\
\hline
\end{tabular}

The assesment of all of the shielding designs showed that the design that posses the minimum value of radiation dose rate is design 2 . The minimum dose rate average also possessed by design 2 . The position of the maximum dose rate in design 1 and 2 is in front of the first layer of beam catcher in the upper part, while in design 3 located in the left side of the main layer. The optimum design chosed is design 2 because it has the minimum dose rate and average dose rate compared to the other designs. The volume of design 1 and 2 are almost similar dan smaller than design 3 , which correspond to the cost, shielding 2 has the lowest cost estimation compared to the other designs.

\section{CONCLUSION AND REMARKS}

Modelling of BNCT facility shield with Kartini Reactor thermal column as neutron source using MCNPX concluded that the best material to absorb neutron and photon radiation with thickness of $10-40 \mathrm{~cm}$ is paraffin and borated polyethylene, whereas thickness of 50$100 \mathrm{~cm}$ is stainless steel 304 and barite concrete. These materials were then combined to design a shielding which must be able to reduce the leaking radiation until the dose rate of $10.42 \mu$ $\mathrm{Sv} /$ hour outside is met. Three designs has been made using two material combination on each of them. The best design is design number 2 which consist of borated polyethylene and barite concrete as main layer with maximum dose rate of $7.0746 \mu \mathrm{Sv} /$ hour located in front of the beam catcher layer on the upper part and average dose rate of $2.58712 \mu \mathrm{Sv} /$ hour. The other considerations are the volume and cost of the shielding. This research should be able to become a reference for future research about neutron and photon radiation shielding.

\section{ACKNOWLEDGMENT}

The author wish to thank the Head of Pusat Sains dan Teknologi Akselerator BATAN Yogyakarta, Dr. Susilo Widodo for the permission to conduct research there and to Ranti Warfi and Adrian Tesalonika as partners conducting researches.

\section{POLICY BRIEF}

The shielding design is met with the BAPETEN safety regulation. Any practical implement of BNCT facility requires a shielding to prevent excess exposure of radiation to radiation workers. The materials are widely proven to be available. The simulation phase is considered to be a success. The next phase, which is the practical implementation, including the development of the BNCT facility and the implementation of the radiation shielding requires the support from the policy maker of the Republic of Indonesia. The BNCT facility is strongly recommended due to the high increase in number of cancers in Indonesia. BNCT is safer and relatively more effective and has less side effects to kill cancer compared to another methods, such as the chemotherapy.

\section{REFERENCES}

Akkurt, I., \& El-Khayatt, A. (2013). The effect of barite proprotion on neutron and gammaray shielding. Annals of nuclear energy 51, $5-9$. 

as Neutron Source Using Monte Carlo N Particle Extended Simulator

Bielajew, A. F. (2001). Fundamentals of The Monte Carlo Method for neutral and charged particle transport. Michigan: The University of Michigan.

Calzada, E. (2011). Reusable shielding material for neutron- and gamma-radiation. Nuclear Instruments and Methods in Physics Research A, 77-80.

Cember, H., \& Johson, T. E. (2009). Introduction to Health Physics. Illinois: The McGrawHill.

Gencel, O. (2011). Determination and calculation of gamma and neutron shielding characteristics of concretes containing different hematite proportions. Annals of Nuclear Energy, 2719-2723.

Ghiasi, H. (2012). A new analytical formula for neutron capture gamma dosecalculations in double-bend mazes in radiation therapy. Reports of practical oncology and radiotherapy, 220-225.

Indonesia, K. B. (2013). Peraturan Kepala Badan Pengawas Tenaga Nuklir Nomor 4 Tahun 2013 Tentang Proteksi dan Keselamatan Radiasi Dalam Pemanfaatan Tenaga Nuklir. Jakarta: BAPETEN.

Irhas. (2013). Dosimetri Boron Neutron Capture Therapy pada Kanker Hati (Hepatocellular Carinoma) Menggunakan MCNP-Code dengan Sumber Netron dari Kolom Termal Reaktor Kartini. Yogyakarta: Universitas Gadjah Mada.

Lamarsh, J. R. (1983). Introduction to Nuclear Engineering. Massachusetts: AddisonWesley.
Pelowitz, D. B. (2008). MCNPX User's Manual. New Mexico: Los Alamos National Laboratory.

Pouryavi, M. (2015). Radiation shielding design of BNCT treatment room for D-T neutron source. Applied Radiation and Isotopes, 90-96.

Protection, I. C. (1975). Report of the task group on Reference Man. ICRP Publication 23. Oxford: Pergamon Press.

Santoso, B. H. (2014). Pemodelan Perisai Radiasi Fasilitas BNCT Dengan Sumber Beamport Tembus Teras Reaktor Kartini Menggunakan MCNP5. Yogyakarta: Universitas Gadjah Mada.

Singh, V. P., \& Badiger, N. (2014). Gamma ray and neutron shielding properties of some alloy materials. Annals of Nuclear Energy, 301-310.

Solleh, M. R., Tajudiin, A. A., Mohamed, A. A., Eid, E. M., Munem, A., Rabir, M. H., . . Yoshiaki, K. (2011). COLLIMATOR AND SHIELDING DESIGN FOR BORON NEUTRON CAPTURE THERAPY (BNCT) FACILITYATTRIIGAMARK II REACTOR. JOURNAL OF NUCLEAR And Related TECHNOOGOIES Volume 8 No.2.

Stella, S. (2011). Design of A Prompt Gamma Neutron Activation Analysis (PGNAA) System for Boron Neutron Capture Therapy (BNCT) using Monte Carlo Code. Pavia: Disertasi, University of Pavia.

Warfi, R. (2015). Optimasi Kolimator Kolom Termal untuk Fasilitas Uji In Vitro dan In Vivo BNCT di Reaktor Kartini Menggunakan Simulator MCNP-X. Yogyakarta: Universitas Gadjah Mada. 